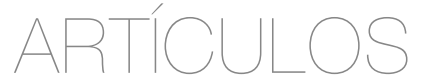

\title{
ORIGINALES
}

\section{Analysis of the Effects of Time Pressure and Supervisor Support on Organizational Cynicism and Employee Surveillance in Organization}

\author{
ZAFER ADIGUZEL* \\ SEVGI NUR KARAALIOGLU** \\ CEMAL ZEHIR ${ }^{\star \star \star ~}$
}

* Phd in Business. İstanbul Medipol Üniversitesi, Medipol Business School, Istanbul, Turkey. E-mail: zadiguzel@medipol.edu.tr. ORCID: 0000-0001-8743-356X. Google Scholar: https://scholar.google.com/citations?user=gqZP7-8AAAAJ\&hl=tr. Scopus Author ID: https://www.scopus.com/authid/detail.uri?authorld=57211239990.

** Bachelor in Health Management. İstanbul Medipol Üniversitesi, Istanbul, Turkey. E-mail: sevgi.karaalioglu@hotmail.com. ORCID: 0000-0002-5015-1275. Google Scholar: https://scholar.google.com/citations?hl=tr\&user=xFhuNpwAAAAJ.

*** Phd in Business. Yildiz Technical University, Istanbul, Turkey. E-mail: czehir@yildiz.edu.tr. ORCID: 0000-0003-2584-4480. GoogleScholar: https://scholar.google.com/citations?hl=tr\&user=He6xmPYAAAAJ\&view_op=list_works\&sortby=pubdate. Scopus Author ID: https://www.scopus.com/authid/detail.uri?authorld=24337148400. 


\section{COMO CITAR ESTE ARTÍCULO}

How to cite this article:

Adiguzel, Z., Karaalioglu, S. and Zehir, C. (2021). Analysis of the Effects of Time Pressure and Supervisor Support on Organizational Cynicism and Employee Surveillance in Organization. Revista Perspectiva Empresarial, 8(1), 7-26.

Recibido: 23 de noviembre de 2020 Aceptado: 02 de marzo de 2021
ABSTRACT Objective. Analyze the relationships between the variables of employee surveillance, supervisor support, organizational cynicism, and time pressure. Methodology. The sample group of the study consists of 417 white-collar employees in private and public sector. After the analysis of the findings were made with the SPSS 25 program, the results were analyzed and evaluated. Analysis data were collected from both public and private institutions operating in Istanbul. Results. As a result of the analysis, it is understood that time pressure and supervisor support have significant effects on organizational cynicism and employee surveillance. Conclusions. With the analysis of the data received in the scope of research model, it may be drawn a conclusion that employees expect support from their supervisors, otherwise they start to move away from the institution.

KEYWORDS Employee surveillance, supervisor support, organizational cynicism, time pressure, Hayes Process.

\section{Análisis de los efectos de la presión del tiempo y el apoyo del supervisor sobre el cinismo organizativo y la vigilancia de los empleados en las organizaciones}

RESUMEN Objetivo. Analizar las relaciones entre las variables de vigilancia de los empleados, apoyo del supervisor, cinismo organizacional y presión del tiempo. Metodología. El grupo de muestra del estudio está formado por 417 empleados de cuello blanco del sector privado y público. Los resultados se analizaron y evaluaron con el programa SPSS 25. LoS datos del análisis se recogieron en instituciones públicas y privadas que operan en Estambul. Resultados. Como resultado del estudio se entiende que la presión del tiempo y el apoyo del supervisor tienen efectos significativos sobre el cinismo organizativo y la vigilancia de los empleados. Conclusiones. Con el análisis de los datos recibidos en el ámbito del modelo de investigación se puede concluir que los empleados esperan el apoyo de sus supervisores, de lo contrario comienzan a alejarse de la institución.

PALABRAs CLAVE vigilancia de los empleados, apoyo del supervisor, cinismo organizacional, presión del tiempo, Proceso Hayes. 


\section{Análise dos efeitos da pressão do tempo e do apoio do supervisor sobre o cinismo organizacional e a vigilância dos funcionários nas organizações}

RESUMO Objetivo. Analise as relações entre as variáveis de vigilância do funcionário, suporte do supervisor, cinismo organizacional e pressão de tempo. Metodologia. 0 grupo de amostra do estudo é composto por 417 funcionários de colarinho branco dos setores público e privado. Os resultados foram analisados e avaliados com o programa SPSS 25. Os dados para análise foram coletados em instituições públicase privadas que operam em Istambul. Resultados. Como resultado do estudo, entendese que a pressão do tempo e o apoio do supervisor têm efeitos significativos no cinismo organizacional e na vigilância dos funcionários. Conclusões. Com a análise dos dados recebidos no âmbito do modelo de pesquisa, pode-se concluir que os funcionários esperam o apoio de seus supervisores, caso contrário, começam a se afastar da instituição.

PALAVRAS CHAVE vigilância do funcionário, suporte do supervisor, cinismo organizacional, pressão do tempo, Processo Hayes. 


\section{Introduction}

Employee surveillance and time pressure have been acknowledged as concepts which cause employees having negative thoughts towards the organization by preventing employees from working efficiently. In this case, the importance of the support of supervisors on employees shows up. When supervisors allow employees to gain job control regarding their own tasks and responsibilities, there may be the opportunity for the employees to manage time better. It is possible that, as a result of feeling the pressure of management and thereby starting to have negative feelings towards the organization within a certain time period and under surveillance, employees intend to withdrawal. When employees do not feel support of management, level of dissatisfaction will begin to increase, which may result decrease in their business manner and performances (Riketta, 2008). It is stated in the literature that if employees get support from the management, they reflect this support positively to the organization and there becomes a significant increase in their performance (Turner etal., 2012). According to some researchers, Cynicism is expressed as the opposite and negative thoughts of employees towards their organization and the occurrence of their defense mechanism against negative behaviors and attitudes that they encountered (Naus, Iterson and Roe, 2007). This defense mechanism may occur when the duties and responsibilities of the employees are too much, when they experience time pressure, and when the speeches and actions of the supervisors different from each other. Kannan-Narasimhan and Lawrence (2012) express organizational cynicism as negative feelings towards their organizations such as hopelessness, disappointment. According to another definition, organizational cynicism is the result of disappointments and unfair organizational processes within the organization (Wilkerson, Evans and Davis, 2008). In order to prevent or eliminate organizational cynicism, supervisors should have positive influence on their employees. Especially right after the supervisors start to support their employees, the employees should perceive this support not as surveillance, but as a support they get in terms of business manner. Employee surveillance is defined as the formal control system of an organization which is trying to prevent unethical behaviors of employees; including controlling and monitoring practices. If the employee surveillance has been made correctly, the employees' incorrect attitudes and behaviors can be prevented. The importance of employee surveillance shows up especially while preventing behaviors which has occurred because of time pressure, such as violating the rules, making changes in terms of business manner, taking decisions which will put the organization into difficult position. According to this perspective, when there are gaps within the organization discipline, employees perceive this as an opportunity and this causes an increase in their undisciplined behaviors. When the employee surveillance has been made with the support of the supervisor, the probability of gaining of both sides would be high. For example, in a research which has been made in the service sector, it has been determined that in the circumstances where there is no employee surveillance, petty larceny within the stores had been overlooked, but with the start of employee surveillance, the employees had started to behave more carefully and thus, the number of petty larceny had started to decrease (Hollinger and Adams, 2014). Within this theoretical scope, in the research model, the effects of time pressure and supervisor support on organizational cynicism and employee surveillance has been analyzed.

\section{Employee Surveillance}

In the literature, in the studies regarding employee surveillance subject, organizational procedures and policies, leadership styles, personality, behaviors and ethical understanding and the relations between them have been analyzed (Meyer et al., 2014; Wiltshire, Bourdage and Lee, 2014). Apart from these studies, we have been examining the effects of time pressure and supervisor support on employee surveillance. The reaction of the employees to their surveillance while they were under time pressure, and also again the reaction of the employees in a work environment where there is supervisor support are important in terms of behaviors and attitudes. With the policies and trainings applied to the employees in the organizations, as a result of the pressure employees feeling who are responsible to do their work under time pressure, employees' attitudes and behaviors towards the organization start to change. Employees' communicative and attitudinal reactions to surveillance, which is applied by management, 
may have an impact on their performance. It is necessary for management to understand how and why employees react to surveillance both communicatively and attitudinally and to find solutions in order to prevent organizational cynicism. There are studies advocating employee surveillance (Sewell and Barker, 2006), as well as there are studies advocating that right of privacy of the employees are fragile and weak, therefore right of privacy should be protected (D'Urso, 2006; Miller and Weckert, 2000). There have been some reactions of the employees against the surveillance they live within the institution such as avoiding themselves from the glance of the supervisors, being disturbed because of the surveillance and leaving the organization (Holmes, 2003), withstanding to the supervisors by arguing with them during the surveillance (Stanton and Stam, 2003), opposing to the surveillance and taking steps like demanding work autonomy. However, it has been also set forth that many so-called resistance movements do not actually damage work efficiency sufficiently (Mason etal., 2002). Some justifications can be put forward regarding the surveillance and autonomy of the employees: employers have been seeing these privileges in themselves such as, gaining control over the workplace, protecting their properties, controlling and also managing employee performance in terms of productivity, quality, training and the importance of consumer interaction (Ciocchetti, 2001; Findlay and McKinlay, 2003). Employers can also give importance on employee surveillance to prevent leakage of confidential information (especially business secrets and strategies) from the organization, deliberately or unintentionally (Lehman, 1997). Within the scope of the research model, we have been examining the effects of time pressure and supervisor support on employee surveillance.

\section{Organizational Cynicism}

When the studies on organizational cynicism are examined, ithas been said this have been accelerated between 1980's and 1990's, and it is a new field compared to the concept of cynicism (Johnson and O'Leary-Kelly, 2003). The organizational cynicism, that employees experience in circumstances where there is lack of honesty and fair behaviors within the organization, occurs mostly by violation of the concepts of justice, morality and honesty. Cynicism concept reminds of the meanings such as doubts about sincerity and goodness, disbelief, dis-valuation, making it a habit to emphasize this dis-valuation with a cynical smile and tendency to find mistakes (Bakker, 2007). James (2005) states that the concept of cynicism is an attitude, which has been characterized with hopelessness, frustration and disappointment. Cynicism has been expressed as disbelief of individuals to the actions towards the attitudes and behaviors in the surrounding (Stanley, Meyer and Topolnytsky, 2005). According to Andersson and Bateman (1997), cynicism, which has been characterized with hopelessness and disappointment, besides being a general and a very special attitude, is the sum of negative feelings towards individuals, groups, ideologies, social mores and institutions. According to Barefoot et al. (1989), cynicism is one's views that show people, other than himself/herself, as self-interested and worthless. For Eaton (2000), while cynicism resembles with the terms "skepticism," "mistrust," "incredulity," "pessimism" and "disbelief," it has also been used contemporaneously with the meanings of "captious," "fussy" and "critic." Organizational cynicism is not only the emotions which were brought to the organization by the cynical people, but also shaping these attitudes through organizational experiences. Thus, organizational cynicism has been conceptualized as a future oriented characteristic and it has been claimed that it represents a "learned thought" which is developed as a result of experiences (Johnson and O'leary-Kelly, 2003). Within this scope, cynicism is indicated as the disbelief of behaviors and attitudes in individuals' sincerity of motivation and goodness. Within the research model, the impacts of time pressure and supervisor support on organizational cynicism have been analyzed.

\section{Time Pressure}

In recent years, changes of organizational structures and management styles, development of technological opportunities have created differences in terms of employees' business manners (Parker, 2014). For example, with the number of increase of virtual business applications, settings of business manners have become more flexible (e.g. home office, flexible working time). At the same time, with the changes in organizational structures, time management has started to come to the forefront. In most European countries, employees have been reporting the time pressure or the increase in their workload/responsibilities, 
in other words they have been complaining about their workload (Prem et al., 2017). Employees have difficulty in finding ways to cope effectively with both time pressure and heavy demands. Time pressure indicates to the psychological pressure because of not having enough time to do the required work (Keinan, Friedland and Ben-Porath, 1987). Time pressure pushes individuals for processing the information more quickly (Pieters and Warlop 1999), and therefore it may affect the accuracy of the decision to be made and the decrease of the quality of the work to be made (Hahn, Lawson and Lee, 2006). Regarding preventing the mistakes caused by time pressure, whether the work autonomy which will be given to the employees will work or not may depend on the tendency of the employees to the organization and also depends on the work they do. For example, de Rijk etal. (1998) state that the relationship between job demands and burnout decreases with high job autonomy and increases with low job autonomy; however, this situation depends on the ability of employees to cope actively with the workload (de Rijk et al., 1998). Moreover, it is also stated that, whether the given autonomy to employees would be beneficial or not, while they were dealing with time pressure, depends on the employees' ability to manage time and also their personal competencies related to the work (Daniels and de Jonge, 2010). Therefore, if the employees believe that they can manage time and control the work generally, the opportunities/potentials that organizations which were provided to them by the organizations should be examined. Within the scope of research model, the effects of time pressure on cynicism and employee surveillance, which are kinds of reactions towards the organization, have been analyzed.

\section{Hypotheses:}

H1: In organizations, time pressure has an impact on supervisor support.

$\mathrm{H}$ 2: In organizations, time pressure has an impact on employee surveillance.

H3: In organizations, time pressure has an impact on organizational cynicism.

\section{Supervisor Support}

Although supervisor support has an impact on the occurrence of organizational support
(Stinglhamber and Vandenberghe, 2003), employees often evaluate the problems with their supervisors as temporary and think that these problems can be overcome in the future. Supervisor support is the primary support which has shown to the employee (Yoon and Lim, 1999). In the studies which have been made regarding perceived supervisor support, it has been emphasized that the employees of an organization who think that they are supported by their supervisors, the negative outputs such as burnout syndrome (Choi, Cheong and Feinberg, 2012), job stress (Halbesleben, 2006), intention to quit (Holman, 2003), recruitment and retraining costs (Dhar, 2012) disappear; while at the same time positive outputs such as support programs in organizations, organizational citizenship behavior (Arshadi, 2011), commitment (Rhoades and Eisenberger, 2002) increases. Tymon Jr., Stumpf and Smith (2011) have determined that when the perception of the employee regarding supervisor support is high, the intention to quit decreases; while the commitmentand the perceived carrier success increases. Newman, Thanacoody and Hui (2011) states that, supervisor support has an impact on the relationship between education and commitment to the organization and yet he also states that it is not an emotional commitment. Perceived supervisor support includes activities such as providing opportunity to employees to develop new abilities, allocating time for employees' career goals and supporting trainings towards their careers (Çakmak-Otluoğlu, 2012), and also includes supports such as solution of work problems and such as balancing private life and business life (Turgut, 2011). To provide the specified support types by the supervisors, to meet the demands and needs of the employees and to create a more appropriate work environment are important in order to develop positive behavior of employees towards the organization so that they would display behaviors which will increase organizational performance. This will also strengthen the connection between the organization and the employee (Lambert and Hogan, 2009). Within the scope of the research model, the impacts of supervisor support on organizational cynicism and employee surveillance have been analyzed, both as an independent variable and as mediation variable.

Hypotheses:

H4: In organizations, supervisor support has an impact on employee surveillance. 
H5: In organizations, supervisor support has an impact on organizational cynicism.

H6: In organizations, supervisor support has mediation variable impact on the relationship between time pressure and employee surveillance.

H7: In organizations, supervisor support has mediation variable impact on the relationship between time pressure and organizational cynicism.

\section{Methodology}

In this research, we aim to determine the impacts of the relationship between time pressure, with the supervisor support mediation variable effect, employee surveillance and organizational cynicism, on white collar employees working in public and private sector. Within the scope of the aim of the study, a survey study with 417 employees has been made. The data obtained have been evaluated with IBM SPSS 25 Statistics Package Software and "descriptive" analysis has been used in demographic information. Factor analysis and reliability analysis have been applied to the questions using Likert scale. Correlation analysis has been used to analyze the relationship between variables, regression analysis has been used to test the hypotheses and Sobel test has been used to analyze the effect of mediation variable. In the first part of the two-part questionnaire, there are questions regarding participants' demographic information and their work. The second part of the questionnaire consists of scales related to employee surveillance, supervisor support, organizational cynicism and time pressure.

The questionnaire consists of questions which represents four variables. In the first part of the questionnaire, there are questions regarding participants' demographic information and their work. In the second part of the questionnaire, there are questions representing four variables. In the research, Time Pressure has been measured by the questions which were used by Semmer, Zapf and Dunckel (1995). Supervisor Support, has been measured by the questions which were used by French, Caplan and van Harrison (1982). Employee Surveillance, the questions which were developed by de Vries and van Gelder (2015) have been used. Organizational Cynicism, the questions which were developed by Dean, Brandes and Dharwadkar (1998), Brandes, Dharwadkar and Dean (1999), and Kalağan (2009) have been used.

\section{Findings}

Our survey has been made in different departments of public (192) and private sector (225), with 417 working people in total. 203 females, 214 male, white collar employees have answered our survey. 246 of the participants were in the 30-40 group of age, while 138 are in the 41-50 group of age. Number of over age 51 is 33. From all the working people who had answered our questionnaire, 353 participants have University degree, 56 participants have Master degree, 8 participants have Ph.D. degree. The descriptive analysis results regarding individual factors have been shown in the table below. The level of achievement of employees' individual goals which were determined by themselves were stated as: 37 participants' level of achievement to their goals "Very Low," 49 participants' level of achievement to their goals "Low," 168 participants' level of achievement to their goals "Intermediate," 131 participants' level of achievement to their goals "High," 32 participants' level of achievement to their goals "Very High." Fields of activity of institutions where the participants work: 132 participants work in "National," 157 participants work in "Regional," 128 participants work in "International" institutions, which they continue their facilities within their fielding.

\section{The scope of research}

Based on literature review, a research model has been implemented in which independent variable is time pressure; mediation variable is supervisor support; dependent variables are employee surveillance and organizational cynicism. In the research, a quantitative approach was adopted as the data were analyzed in order to determine the relationship between statistical concepts. In a quantitative research test, we use the independent variable or variables in order to judge the effect on the dependent variable (Thomas, Nelson and Silverman, 2015). 


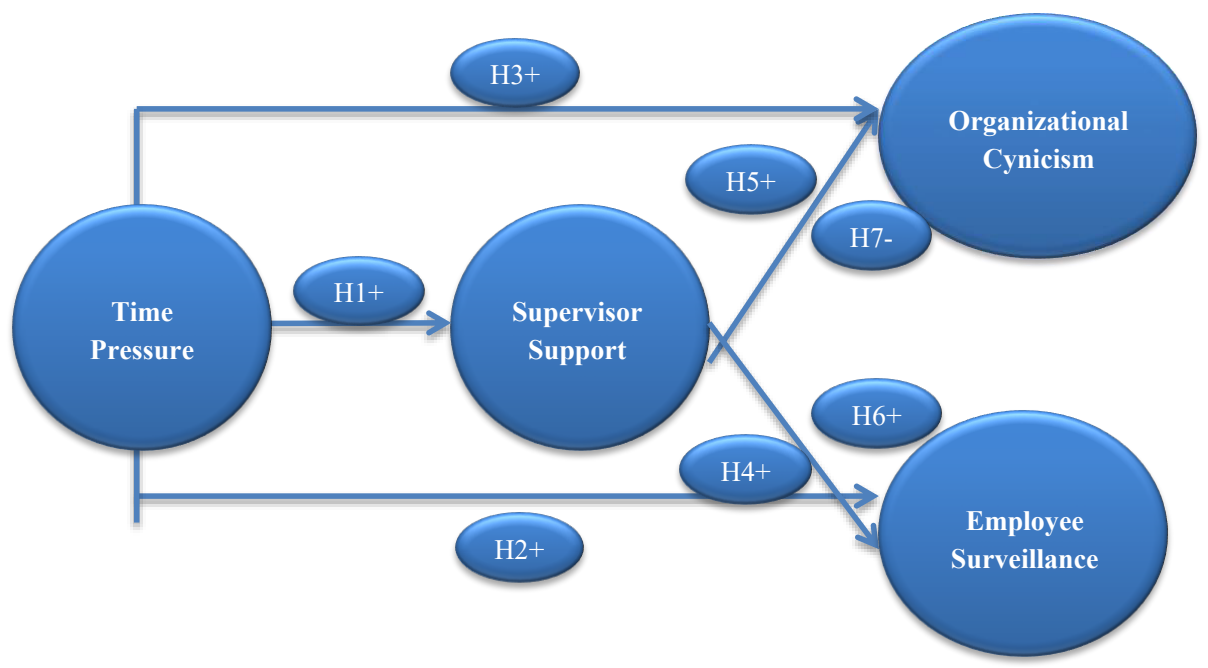

Figure 1. Research Model. Source: author's own elaboration.

\section{Results}

Factor analysis has bene made in order to investigate the construct validity of the scale. Within the variables which have been measured with a 35 question questionnaire, 7 questions were eliminated since they haven't shown factorial distribution. The remaining 28 questions has been scattered by 4 factors. Çokluk, Şekercioğlu and Büyüköztürk (2012) haven't been identifying factor analysis as a multivariable statistical method which aims to find out a few number of unrelated, conceptually significant new variables (factors, dimensions) by bringing together the related variables. KaiserMeyer Olkin - KMO- sample compliance test has been made in order to determine whether the data obtained from the preliminary application were suitable for factor analysis or not, and the diagonal values of the anti-image correlation matrix were examined with Bartlett's sphericity test. KaiserMeyer-Olkin sample compliance value was 0.961 and Bartlett's sphericity test had a significance level of 0.000 (for $p \leq 0.05$ ), indicating that the data were appropriate for factor analysis. In order to bring the data set into a form that can be analysed by factor analysis, 4 factors were formed as a result of the principal component analysis. The results obtained have been shown in Table 1 .

Table 1. Rotated Component Matrix ${ }^{a}$

\begin{tabular}{|c|c|c|c|c|}
\hline \multicolumn{5}{|l|}{ Rotated Component Matrix ${ }^{a}$} \\
\hline & \multicolumn{4}{|c|}{ Component } \\
\hline & 1 & 2 & 3 & 4 \\
\hline ES6. I regularly report to my supervisor about my work, in the institution I work for. & 0.838 & & & \\
\hline ES7. Our correspondence is audited in the institution I work for. & 0.828 & & & \\
\hline ES2. I am held responsible for every operation I do in the institution I work for. & 0.784 & & & \\
\hline $\begin{array}{l}\text { ES4. Our work entrance and exit hours are always under control in the institution I } \\
\text { work for. }\end{array}$ & 0.783 & & & \\
\hline $\begin{array}{l}\text { ES5. I do not have the authority to sign my work, without permission of my supervisor } \\
\text { in the institution I work for. }\end{array}$ & 0.776 & & & \\
\hline
\end{tabular}




\section{Rotated Component Matrix}

\begin{tabular}{|c|c|c|c|c|}
\hline & \multicolumn{4}{|c|}{ Component } \\
\hline & 1 & 2 & 3 & 4 \\
\hline ES8. Supervisors monitor the employees regularly, in the institution I work for. & 0.774 & & & \\
\hline $\begin{array}{l}\text { ES1. Even if we have the authority, we still have to get permission of our supervisor, } \\
\text { in the institution I work for. }\end{array}$ & 0.773 & & & \\
\hline SS7. Supervisors care about welfare of the employees, in the institution I work for. & & 0.724 & & \\
\hline SS13. Managers support us to in order to correct our mistakes in the institution I work for. & & 0.714 & & \\
\hline SS10. The supervisors care about their employees' thoughts, in the institution I work for. & & 0.706 & & \\
\hline SS4. Supervisors are good role models for the employees, in the institution I work for. & & 0.701 & & \\
\hline $\begin{array}{l}\text { SS6. When we overwork because of workload, supervisors work with us in order to } \\
\text { finish the work in time, in the institution I work for. }\end{array}$ & & 0.701 & & \\
\hline $\begin{array}{l}\text { SS12. Supervisors provide important information and advice to us that make it easier } \\
\text { for us to do things, in the institution I work for. }\end{array}$ & & 0.687 & & \\
\hline SS8. Supervisors support us regarding carrier, in the institution I work for. & & 0.665 & & \\
\hline $\begin{array}{l}\text { OC18. I am concerned about the thoughts of top management, in the institution I } \\
\text { work for. }\end{array}$ & & & 0.789 & \\
\hline $\begin{array}{l}\text { OC12. The policies, objectives and practices of top management do not coincide with } \\
\text { the opinions of the employees in the institution I work for. }\end{array}$ & & & 0.773 & \\
\hline OC16. I feel anxious when I think about top management, in the institution I work for. & & & 0.762 & \\
\hline OC10. Management doesn't care about employees' thoughts in the institution I work for. & & & 0.727 & \\
\hline $\begin{array}{l}\text { OC6. We feel that we are not taken seriously by top management, in the institution } \\
\text { I work for. }\end{array}$ & & & 0.724 & \\
\hline OC11. Top management does the opposite of what it says in the institution I work for. & & & 0.721 & \\
\hline $\begin{array}{l}\text { OC17. When I think about the attitude of the top management towards the employees, } \\
\text { I get nervous, in the institution I work for. }\end{array}$ & & & 0.691 & \\
\hline $\begin{array}{l}\text { OC9. I have the same thoughts with my colleagues regarding the inadequacy of } \\
\text { management. }\end{array}$ & & & 0.656 & \\
\hline TP5. The deadlines for fulfilling the tasks which were given to us are usually short. & & & & 0.737 \\
\hline $\begin{array}{l}\text { TP4. Since new tasks are constantly given, I have to fulfill my work in a time shorter } \\
\text { than the deadline. }\end{array}$ & & & & 0.731 \\
\hline TP3. I can't find time to take a break during working hours. & & & & 0.629 \\
\hline TP7. We also have to work on weekends to fulfill our tasks. & & & & 0.617 \\
\hline TP6. We are usually under a lot of pressure to fulfill our tasks on time. & & & & 0.610 \\
\hline TP8. We go beyond our plans to complete our missions, within limited time. & & & & 0.510 \\
\hline
\end{tabular}

Note: a. Rotation converged in 5 iterations; ES: Employee Surveillance; SS: Supervisor Support; OC: Organizational Cynicism; TP: Time Pressure. 
In the research, Cronbach Alpha test was used for internal consistency reliability tests. This test determines the consistency of the items in the measurement tools and whether the items measure the relevant concept or not. To calculate the alpha value, the probable halves of all items in the measuring tool are constituted, the total scores of these halves are calculated and the coefficients of correlation between these halves are calculated. Alpha value is the average amount of these coefficients of correlation (Cronbach, 1951).

Cronbach's alpha coefficient is calculated in the graded tests such as Likert scale, in which the answers of the articles were not guided correctly or incorrectly (Thorndike et al., 1991). The fact of the calculated coefficient being above the expected level gives information regarding the applicability of the developed scale to participants from different cultures and socio-economic levels. Within this context, the relevant scale can be considered as a powerful and sufficient measurement tool. The alpha coefficient is usually expected to be above 0.7 (Nunnally, 1978; Hair, Bush and Ortinau, 2000; Büyüköztürk, 2007).

Table 2. Reliability Tests

\begin{tabular}{lll}
\hline \multicolumn{1}{c}{ Variables } & $\begin{array}{c}\text { Number of } \\
\text { Questions }\end{array}$ & $\begin{array}{c}\text { Cronbach Alpha } \\
\text { (a) Values }\end{array}$ \\
\hline Employee Surveillance & 7 & 0.942 \\
\hline Supervisor Support & 7 & 0.914 \\
\hline Organizational Cynicism & 8 & 0.905 \\
\hline Time Pressure & 6 & 0.890 \\
\hline
\end{tabular}

Source: author's own elaboration.

\section{Correlation analysis}

One to one relationship between employee surveillance, supervisor support, organizational cynicism, time pressure has been discussed. As we have mentioned earlier, analyzes until now (factor analysis, reliability analysis, descriptive analysis) were conducted on 417 questionnaires obtained from institutions.

The most commonly used significance tests in statistical analysis have been regression tests and correlation tests. These tests have been used to measure the relationships between the variables involved in the study and their degree of influence each other. Both the relationship and the direction and degree of the relationship have been determined by the relevant tests. The functional relationship between variables has been examined with regression analysis and the percentage level of this relationship has been examined with correlation. In order to make the regression and correlation analyzes, first of all, the conditions of normal distribution and homogeneity, which are the assumptions of these analyzes, must be tested. However, it is not always possible for the researches which have been made in the social sciences and which have been measured by Likert to be normally distributed. In this case, values of skewness and kurtosis are examined and if the condition is provided, it is accepted that it is distributed normally (Tabachnick, Fidell and Ullman, 2007).

In order to summarize the large amount of numerical data obtained from the researches, with a few simple expressions, descriptive statistics have been used (Johnson, 1980; Linquist, 1989). Descriptive statistics contain summary information such as number of times each value or value set within a variable repeats itself, how the values distribute around a selected central point, how far they are to the central point or to each other relatively. 
Table 3. Correlations

\begin{tabular}{|c|c|c|c|c|c|}
\hline \multicolumn{6}{|l|}{ Correlations } \\
\hline & & $\begin{array}{c}\text { Employee } \\
\text { Surveillance }\end{array}$ & $\begin{array}{c}\text { Supervisor } \\
\text { Support }\end{array}$ & $\begin{array}{l}\text { Organizational } \\
\text { Cynicism }\end{array}$ & $\begin{array}{c}\text { Time } \\
\text { Pressure }\end{array}$ \\
\hline \multirow{3}{*}{$\begin{array}{l}\text { Employee } \\
\text { Surveillance }\end{array}$} & Pearson Correlation & 1 & $0.873^{\star *}$ & $0.505^{\star \star}$ & $0.703^{\star *}$ \\
\hline & Sig. (2-tailed) & & 0.000 & 0.000 & 0.000 \\
\hline & $\mathrm{N}$ & 417 & 417 & 417 & 417 \\
\hline \multirow{3}{*}{$\begin{array}{l}\text { Supervisor } \\
\text { Support }\end{array}$} & Pearson Correlation & $0.873^{\star \star}$ & 1 & $-0.515^{\star \star}$ & $0.747^{\star \star}$ \\
\hline & Sig. (2-tailed) & 0.000 & & 0.000 & 0.000 \\
\hline & $\mathrm{N}$ & 417 & 417 & 417 & 417 \\
\hline \multirow{3}{*}{$\begin{array}{l}\text { Organizational } \\
\text { Cynicism }\end{array}$} & Pearson Correlation & $0.505^{\star \star}$ & $-0.515^{\star \star}$ & 1 & $0.646^{\star \star}$ \\
\hline & Sig. (2-tailed) & 0.000 & 0.000 & & 0.000 \\
\hline & $\mathrm{N}$ & 417 & 417 & 417 & 417 \\
\hline \multirow{3}{*}{$\begin{array}{l}\text { Time } \\
\text { Pressure }\end{array}$} & Pearson Correlation & $0.703^{\star *}$ & $0.747^{\star *}$ & $0.646^{\star *}$ & 1 \\
\hline & Sig. (2-tailed) & 0.000 & 0.000 & 0.000 & \\
\hline & $\mathrm{N}$ & 417 & 417 & 417 & 417 \\
\hline
\end{tabular}

Note: ${ }^{\star \star}$ Correlation is significant at the 0.01 level (2-tailed).

Source: author's own elaboration.

In order to examine the degree and direction of the linear relationships between the variables Pearson correlation coefficient is calculated (Sipahi, Yurtkoru ve Çinko, 2006). In order to determine the presence and direction of the significant relationship between Employee Surveillance, Supervisor Support, Organizational Cynicism and Time Pressure, Pearson correlation analysis has been used.
In order to test the impact of employee surveillance, supervisor support, organizational cynicism and time pressure on each other, simple linear regression analysis has been used. Regression analysis is the separation of two or more variables as one of them becoming dependent variable, while the others become as independent variables, and the explanation of the relationship between them with a mathematical equation (Büyüköztürk et al., 2013).

Table 4. Regression Analysis Results

\begin{tabular}{|c|c|c|c|c|c|}
\hline IV & DV & Standard $\beta$ & Sig. & Adjusted R Square & FValue \\
\hline Time Pressure & Supervisor Support & $0.747^{\star \star \star}$ & 0.000 & 0.557 & 523.632 \\
\hline Time Pressure & Employee Surveillance & $0.703^{* \star *}$ & 0.000 & 0.493 & 405.658 \\
\hline Time Pressure & Organizational Cynicism & $0.646^{\star * *}$ & 0.000 & 0.416 & 297.774 \\
\hline Supervisor Support & Employee Surveillance & $0.873^{\star \star *}$ & 0.000 & 0.761 & 1326.022 \\
\hline Supervisor Support & Organizational Cynicism & $-0.515^{\star * \star}$ & 0.000 & 0.264 & 150.074 \\
\hline
\end{tabular}

Note: ${ }^{\star} p<0.05 ;{ }^{\star \star} p<0.01 ;{ }^{* \star *} p<0.001$. 
One of the primary functions of scientific researches is to establish a cause effect relationship between the variables. Statistical analysis explaining all these relationships have been made by regression analysis. In regression analysis, while the relationship between variables has been investigated, the impact degree of the change in independent variables on the dependent variable is being examined. It has been presented the extent to which one-unit increase in the independent variable will increase or decrease on the dependent variable. Evaluation of the relationships determined by correlation analysis has been made within the context of cause and effect by regression analysis.

As a result of regression analysis, the time pressure independent variable has impact on supervisor support, employee surveillance and organizational cynicism. At the same time, supervisor support variable has a positive and significant impact on employee surveillance, while it has a negative impact on organizational cynicism variable. This may have been perceived in the organizations in which supervisor support exists, as the disappearance of organizational cynicism.

\section{Supported and Unsupported Hypotheses Based on Regression Analysis Results}

The hypotheses which were foreseen within the scope of the research model have been tested and the hypotheses results, except the impact of the mediation variable, have been given in Table 5 .

Table 5. Hypothesis Results

\begin{tabular}{lll}
\hline Hypotheses & $\begin{array}{c}\text { Supported/ } \\
\text { Unsupported }\end{array}$ & $\begin{array}{c}\text { Significance } \\
\text { Level (Sig.) }\end{array}$ \\
\hline H1: In organizations, time pressure has an impact on supervisor support. & Supported & P<0.001 \\
\hline $\mathrm{H}_{2}$ In organizations, time pressure has an impact on employee surveillance. & Supported & P<0.001 \\
\hline $\mathrm{H}_{3}$ : In organizations, time pressure has an impact on organizational cynicism. & Supported & P<0.001 \\
\hline $\mathrm{H}_{4}$ : In organizations, supervisor support has an impact on employee surveillance. & Supported & P<0.001 \\
\hline $\mathrm{H}_{5}$ : In organizations, supervisor support has an impact on organizational cynicism. & Supported & P<0.001 \\
\hline
\end{tabular}

Source: author's own elaboration.

\section{Determination of Mediation Variable Effect in Research Model}

In the research model, for the determination of the impact of the mediation variable, especially of supervisor support, while it has a significant and positive impact on the relationship between time pressure independent variable (IV) and employee surveillance dependent variable (DV), the role of the mediation variable in the relationship between time pressure independent variable and organizational cynicism dependent variable disappears and has no effect. The results of the mediation variable effect the analysis has been shown in Table 6 .

Table 6. The Effect of the Mediation Variable (MV)

\begin{tabular}{cllllll}
\hline & \multicolumn{1}{c}{ IV } & DV & Standard $\boldsymbol{B}$ & Sig. & $\begin{array}{c}\text { Adjusted R } \\
\text { Square }\end{array}$ & \multicolumn{1}{c}{ FValue } \\
\hline \multirow{2}{*}{ Regression } & Time Pressure & Employee Surveillance & $\mathbf{0 . 1 1 6 * * *}$ & $\mathbf{0 . 0 0 0}$ & $\mathbf{0 . 4 9 3}$ & 405.658 \\
\cline { 2 - 7 } & Supervisor Support & & $\mathbf{0 . 7 8 6 * * *}$ & $\mathbf{0 . 0 0 0}$ & $\mathbf{0 . 7 6 6}$ & 683.595 \\
\hline
\end{tabular}




\begin{tabular}{|c|c|c|c|c|c|c|}
\hline & IV & DV & Standard $\beta$ & Sig. & $\begin{array}{c}\text { Adjusted R } \\
\text { Square }\end{array}$ & F Value \\
\hline \multirow{2}{*}{ Regression } & Time Pressure & \multirow{2}{*}{ Organizational Cynicism } & $0.591^{* * *}$ & 0.000 & 0.416 & 297.774 \\
\hline & Supervisor Support & & 0.074 & 0.191 & 0.417 & 150.001 \\
\hline
\end{tabular}

Note: ${ }^{\star} p<0.05 ;{ }^{\star \star} p<0.01 ;{ }^{* \star *} p<0.001$.

Source: author's own elaboration.

In order to explain the effect of the mediation variable, it is necessary to determine whether its impact between the independent variable and the dependent variable is significant or not. One of the tests measuring the effect of this mediation variable is the Sobel (1982) test. For analyze the impact of the mediation variable by Sobel test, it is calculated the uncorrected regression coefficients and standard error values of the related variables. In 1995, MacKinnon, Warsi, and Dwyer have extended the statistical methods, by which mediation variable impact they can be evaluated. There are two main versions of the Sobel test, Aroian (1947) and Goodman (1960).

Table 7. Sobel Test

\begin{tabular}{|c|c|c|c|c|c|c|c|}
\hline \multicolumn{8}{|c|}{$\begin{array}{l}\text { Sobel/Aroian/Goodman Analysis } \\
\text { Determining whether or not supervisor support mediation variable has an impact on the relationship between time pressure } \\
\text { and employee surveillance }\end{array}$} \\
\hline & & & Input & & Test statistic & Std. Error & p-value \\
\hline $\begin{array}{l}\text { Independent } \\
\text { Variable }\end{array}$ & Time Pressure & $\mathrm{a}$ & 0.848 & Sobel test: & 15.93024763 & 0.0448214 & 0 \\
\hline \multirow[t]{2}{*}{ Mediation Variable } & Supervisor Support & $b$ & 0.842 & Aroian test: & $15 \cdot 92241564$ & 0.04484345 & 0 \\
\hline & & Sa & 0.037 & Goodman test: & 15.93809118 & 0.04479934 & 0 \\
\hline $\begin{array}{l}\text { Dependent } \\
\text { Variable }\end{array}$ & $\begin{array}{l}\text { Employee } \\
\text { Surveillance }\end{array}$ & $\mathrm{Sb}$ & 0.038 & & & & \\
\hline \multicolumn{8}{|c|}{ We can explain that there is an impact of the mediation variable among the variables because, $p$ value is less than $<0.05$. } \\
\hline \multicolumn{8}{|c|}{$\begin{array}{l}\text { Sobel/Aroian/Goodman Analysis } \\
\text { Determining whether or not supervisor support mediation variable has an impact on the relationship between time pressure } \\
\text { and organizational cynicism }\end{array}$} \\
\hline & & & Input & & Test statistic & Std. Error & p-value \\
\hline $\begin{array}{l}\text { Independent } \\
\text { Variable }\end{array}$ & Time Pressure & $\mathrm{a}$ & 0.848 & Sobel test: & 1.31490378 & 0.03482536 & 0.18854224 \\
\hline \multirow[t]{2}{*}{ Mediation Variable } & Supervisor Support & $b$ & 0.054 & Aroian test: & 1.31365804 & 0.03485839 & 0.18896131 \\
\hline & & $\mathrm{Sa}$ & 0.037 & Goodman test: & 1.31615307 & 0.03479231 & 0.18812267 \\
\hline $\begin{array}{l}\text { Dependent } \\
\text { Variable }\end{array}$ & $\begin{array}{l}\text { Organizational } \\
\text { Cynicism }\end{array}$ & & & & & & \\
\hline
\end{tabular}


In his researches, Hayes (2017) made a SPSS program through a macro, where developed a data analysis method that examines the effects of mediation. In accordance with the research model, the mediation variable effect was analyzed in model 4.

Table 8. Hayes Process

\begin{tabular}{|c|c|}
\hline $\begin{array}{l}\text { H6: Analysis of the mediation variable effect of supervisor } \\
\text { support in the relationship between time pressure and } \\
\text { employee surveillance with hayes process. }\end{array}$ & $\begin{array}{l}\mathrm{H}_{7} \text { : Analyzing the mediation variable effect of supervisor } \\
\text { support in the relationship between time pressure and } \\
\text { organizational cynicism with hayes process. }\end{array}$ \\
\hline PROCESS Procedure for SPSS Version 3.4 & PROCESS Procedure for SPSS Version 3.4 \\
\hline Y: Employee & Y: Organiza \\
\hline X:TimePres & $X:$ TimePres \\
\hline M: Supervis & M: Supervis \\
\hline Sample & Sample \\
\hline Size: 417 & Size: 417 \\
\hline Indirect effect(s) of X on Y: & Indirect effect(s) of X on Y: \\
\hline Effect BootSE BootLLCI BootULCI & Effect BootSE BootLLCI BootULCI \\
\hline Supervis $0.7139 ; 0.0508 ; 0.6188 ; 0.8161$ & Supervis $0.0458 ; 0.0426 ;-0.0422 ; 0.1260$ \\
\hline Partially standardized indirect effect(s) of X on Y: & Partially standardized indirect effect(s) of X on Y: \\
\hline Effect BootSE BootLLCI BootULCI & Effect BootSE BootLLCI BootULCI \\
\hline Supervis $0.7974 ; 0.0467 ; 0.7113 ; 0.8950$ & Supervis $0.0748 ; 0.0696 ;-0.0685 ; 0.2056$ \\
\hline Completely standardized indirect effect(s) of X on Y: & Completely standardized indirect effect(s) of X on Y: \\
\hline Effect BootSE BootLLCI BootULCI & Effect BootSE BootLLCI BootULCI \\
\hline Supervis $0.5872 ; 0.0359 ; 0.5191 ; 0.6592$ & Supervis $0.0550 ; 0.0507 ;-0.0517 ; 0.1485$ \\
\hline
\end{tabular}

Source: author's own elaboration.

In the analysis of whether there is an effect of the "Supervisor Support" mediation variable for the $\mathrm{H} 6$ hypothesis, the result of indirect effect (s) of $\mathrm{X}$ on $\mathrm{Y}$ is examined. Since there is no " 0 " value between BootLLCI and BootULCI, it is verified that the "Supervisor Support" mediation variable also has a significant effect on the Hayes process test.

In the analysis of whether there is an effect of the "Supervisor Support" mediation variable for $\mathrm{H} 7$ hypothesis has effect, the result of indirect effect (s) of X on Y is examined. Since there is " 0 " value between BootLLCI and BootULCI, it is verified that the "Supervisor Support" mediation variable also has a no significant effect on the Hayes process test.

Hypothesis results in the consequence of regression analysis and Sobel test, have been given in Table 9. 
Table 9. Hypothesis Testing Mediation Variable Impact

\begin{tabular}{llc}
\hline Hypotheses & Supported/Unsupported & Significance Level(Sig.) \\
\hline $\begin{array}{l}\text { H6: In organizations, supervisor support has mediation variable impact } \\
\text { on the relationship between time pressure and employee surveillance. }\end{array}$ & Supported & P $\mathbf{0 . 0 0 1}$ \\
\hline $\begin{array}{l}\text { H7: In organizations, supervisor support has mediation variable impact } \\
\text { on the relationship between time pressure and organizational cynicism. }\end{array}$ & Unsupported & \\
\hline
\end{tabular}

Source: author's own elaboration.

In the research model, where the mediation variable impact of supervisor support was measured, the H6 hypothesis was supported and H7 hypothesis was not supported.

\section{Discussion}

Supervisors have a much greater role than thought in increasing the commitment of employees to the organization. Supervisors should be aware of their employees' ability, contribution, should provide the necessary practices for empowering employees and also should manage employees' career plans in line with their goals (Tymon Jr., Stumpf and Smith, 2010). Supervisor support should also have impact on rewarding employees' contributions to the organization. In return for the success of the employees, also intangible awards should be given and the employees should be congratulated for their work. Thus, employees would have more positive feelings about their work (Thomas and Tymon Jr., 1997). With the impact of Supervisor Support on employees, it is possible to create belonging and empathy feelings of employees towards the organization (Thoits, 2011). Therefore, supervisor support is a valuable resource, which can help employees obtaining physical, mental and emotional energy. However, employees who are under time pressure cannot feel supervisor support and can experience organizational cynicism. Wilkerson (2002), defines organizational cynicism as the occurrence of negative behaviors towards the organization because of the procedures, processes and management which were applied in the organization against the employees. In the study, the impacts of time pressure and supervisor support on organizational cynicism and employee surveillance has been examined and evaluated. Organizational cynicism is a situation of negative thinking and behavior that has occurred because of the loss of criterions that employees value such as equality, justice and ethics and also has occurred because of the unethical attitudes and behaviors applied by the supervisors. At the same time, it has been claimed that organizational cynicism will occur as a result of having unrealistic high expectations, getting disappointment if these expectations are not met and being frustrated after this disappointment (Andersson, 1996). Indeed, Wanous, Reichers and Austin (2000) argues that the concept of organizational cynicism is a learned reaction rather than a personal predisposition. In Brown and Cregan's (2008) explanation, the core belief in organizational cynicism is the sacrifice of feelings such as honesty, justice and sincerity because of personal interests. The change in the attitude and behavior of the employees and the predominance of their negative thoughts because of the time pressure they live within the organization, trigger the occurrence of organizational cynicism. Therefore, we have been emphasizing the importance supervisor support under the impact of mediation variable. Especially the lack of mediation variable effect of supervisor support between time pressure and organizational cynicism variables has been indicating the severity of time pressure employees live. When there is time pressure, it is required to give employees more work autonomy along at the same with supervisor support. Therefore, further research is required regarding reducing the negative impacts of time pressure. It has been thought that, it would be more beneficial to cope with time pressure, given work autonomy to the employees, doing time management by supervisors only to make the employees to do the job correctly and without applying any pressure on them. 


\section{Conclusion}

Time pressure can be explained in different ways. In some studies, it is described as violence on employees by cutting the wages for each additional hour or for each additional minute which has been spent (Komorita and Barnes, 1969; Yukl et al., 1976). As in some studies, it is emphasized that time pressure is not about spending more or less time, and that they feel time pressure psychologically according to the nature of the task assigned to them (Carnevale and Lawler, 1986; Kelley, Beckman and Fischer, 1976). It is stated that, it is possible to have problems because of time pressure, both within employees and between supervisors and employees (Yukl et al., 1976). The reason for this is that, it is possible for employees, who would like to fulfill their responsibilities with success, to have negative thoughts towards both their supervisors and their organizations because of the time pressure they feel. At the forefront of these negative thoughts, the concept of cynicism against the organization exists. Since 1980's, the concept of cynicism has begun to develop in the organizational sense. Organizational cynicism is an important term which is an interdisciplinary subject in every field of human resources (James, 2005). In the research which had been made by Dean, Brandes and Dharwadkar (1998), organizational cynicism is stated as consisting the employee's negative beliefs and feelings towards the organization, whether openly or secretly. These negative attitudes include thoughts about the organization's lack of rightness and honesty, and also include negative feelings and behaviors of the employee towards the organization. In another definition, organizational cynicism has been expressed as a concept characterized by individuals' attitudes, negative beliefs, emotions and similar behaviors towards the organization he/she works, but also has been expressed as a response to the history of social and individual experiences that may change with environmental factors (James, 2005). In the study, with the analyses of the findings, it has been explained that time pressure and supervisor support have impacts on organizational cynicism in different manners. While time pressure increases organizational cynicism, the level of organizational cynicism decreases when there is supervisor support. The prior condition for the employee to be aware that he is supported by the organization is that he feels that he has been supported by his supervisor and that the work done has been valuable (Rhoades and Eisenberger, 2002). Because the employee sees his supervisor as the representative of the organization and he knows that his supervisor has the authority to manage and evaluate on behalf of the organization. Therefore, if the employee feels that the taken decisions and the practices are in his best interest, this would have a positive impact on the employee's perception of organizational support (Yoon and Suh, 2003). Supervisor support is important for the employees. Because the perception of having supervisor support increases the employee's performance and job satisfaction and ensures his loyalty to the organization, decreases the negative feelings and behaviors towards absenteeism and withdrawal (Rhoades and Eisenberger, 2002). For future studies, it would be beneficial to examine the different impacts of time management and time pressure in the organizational sense. Within the fierce competition environment, time management will become more prominentand this will make the studies in this field more valuable.

\section{References}

Andersson, L.M. (1996). Employee cynicism: An examination using a contract violation framework. Human Relations, 49(11), 13951418.

Andersson, L.M. and Bateman, T.S. (1997). Cynicism in the work place: Some causes and effects. Journal of Organizational Behavior, 18(5), 449-469.

Aroian, L.A. (1947). The probability function of the product of two normally distributed variables. Annals of Mathematical Statistics, 18(2), 265-271.

Arshadi, N. (2011). The relationships of perceived organizational support (POS) with organizational commitment, in-role performance, and turnover intention: Mediating role of felt obligation. Procedia-Social and Behavioral Sciences, 30, 1103-1108. 
Bakker, E.D. (2007). Integrity and cynicism: Possibilities and constraints of moral communication. Journal of Agricultural and Environmental Ethics, 20, 119-136.

Barefoot, J.C. et al. (1989). The cook-medley hostility scale: Item content and ability to predict survival. Psychosomatic Medicine, 51(1), 46-57.

Brandes, P., Dharwadkar, R. and Dean, J.W. (1999). Does organizational cynicism matter? Employee and supervisor perspectives on work outcomes. Eastern Academy of Management Proceedings, 2, 150-153.

Brown, M. and Cregan, C. (2008). Organizational change cynicism: The role of employee involvement. Human Resource Management, 47(4), 667-686.

Büyüköztürk, S. (2007). Sosyal bilimler için veri analizi el kitabı. Ankara, Turkish: Pegem Akademi.

Büyüköztürk, S. et al. (2013). Bilimsel araştırma yöntemleri. Ankara, Turkish: Pegem Akademi.

Carnevale, P.J.D. and Lawler, E.J. (1986). Time pressure and the development of integrative agreements in bilateral negotiations. Journal of Conflict Resolution, 30, 636-659.

Choi, S., Cheong, K. and Feinberg, R.A. (2012). Moderating effects of supervisor support, monetary rewards, and career paths on the relationship between job burnout and turnover intentions in the context of call centers. Managing Service Quality: An International Journal, 22(5), 492-516.

Ciocchetti, C. (2001). Monitoring employee e-mail: Efficient workplaces vs. employee privacy. Duke Law \& Technology Review, 0026, 1-11.

Cronbach, L.J. (1951). Coefficient alpha and the internal structure of tests. Psychometrika, 16(3), 297-334.

Çakmak-Otluoğlu, K.Ö. (2012). Protean and Boundaryless Career Attitudes and Organizational Commitment: The Effects of Perceived Supervisor Support. Journal of Vocational Behaviour, 80(3), 638-646.

Çokluk, Ö., Şekercioğlu, G. ve Büyüköztürk, Ş. (2012). Sosyal bilimler için çok değișkenli istatistik: SPSS ve LISREL uygulamaları. Ankara, Turkish: Pegem Akademi.

Daniels, K. and de Jonge, J. (2010). Match making and match breaking: The nature of match within and around job design. Journal of Occupational and Organizational Psychology, 83(1), 1-16.

Dean, J.W., Brandes, P. and Dharwadkar, R. (1998). Organizational cynicism. The Academy of Management Review, 23(2), 341-352.

de Rijk, A.E. et al. (1998). Active coping and need for control as moderators of the job demandcontrol model: Effects on burnout. Journal of Occupational and Organizational Psychology, 71(1), 1-18.

de Vries, R.E. and van Gelder, J.L. (2015). Explaining workplace delinquency: The role of HonestyHumility, ethical culture, and employee surveillance. Personality and Individual Differences, 86, 112-116.

Dhar, R.L. (2012). Employees' perception of organizational support: A qualitative investigation in the Indian information technology (IT) industry. Work, 43(2), 211-222.

D’Urso, S.C. (2006). Who's watching us at work? Toward a structural-perceptual model of electronic monitoring and surveillance in organizations. Communication Theory, 16(3), 281-303.

Eaton, J.A. (2000). A social motivation approach to organizational cynicism. Toronto, Canada: York University.

Findlay, P. and McKinlay, A. (2003). Surveillance, electronic communications technologies and regulation. Industrial Relations Journal, 34(4), 305-318.

French, J.R., Caplan, R.D. and Van Harrison, R. (1982). The mechanisms ofjob stress and strain. New York, USA: Wiley. 
Goodman, L.A. (1960). On the exact variance of products. Journal of the American Statistical Association, 55(292), 708-713.

Hahn, M., Lawson, R. and Lee, Y.G. (1992). The effects of time pressure and information load on decision quality. Psychology \& Marketing, 9(5), 365-378.

Hair, J.F., Bush, R.P. and Ortinau, D.J. (2000). Marketing research: A practical approach for the new millennium. New York, USA: Richard D. Irwin.

Halbesleben, J.R. (2006). Sources of social support and burnout: a meta-analytic test of the conservation of resources model. Journal of Applied Psychology, 91(5), 1134-1145.

Hayes, A.F. (2017). Introduction to mediation, moderation, and conditional process analysis: A regression-based approach. New York, USA: Guilford Press.

Hollinger, R.C. and Adams, A. (2014). 2012 National Retail Security Survey final report. Gainesville, USA: University of Florida.

Holman, D. (2003). Phoning in sick? An overview of employee stress in call centres. Leadership \& Organization Development Journal, 24(3), 123-130.

Holmes, J. (2003). Formulating an effective computer use policy. Information Strategy: The Executive's Journal, 20(1), 26-32.

James, M.S. (2005). Antecedents and consequences of cynicism in organizations: An examination of the potential positive and negative effects on school systems. Tallahassee, USA: Florida State University.

Johnson, R. (1980). Elementary statistics. Belmont, USA: Wadsworth Inc.

Johnson, J.L. and O'Leary-Kelly, A.M. (2003). The effects of psychological contract breach and organizational cynicism: Not all social exchange violations are created equal. Journal of Organizational Behavior: The International Journal of Industrial, Occupational and
Organizational Psychology and Behavior, 24(5), 627-647.

Kalağan, G. (2009). Araştırma görevlilerinin örgütsel destek algıları ile örgütsel sinizm tutumları arasındaki ilişki. Antalya, Turkish: Akdeniz Üniversitesi.

Kannan-Narasimhan, R. and Lawrence, B.S. (2012). Behavioral integrity: How leader referents and trust matter to workplace outcomes. Journal of Business Ethics, 111(2), 165-178.

Keinan, G., Friedland, N. and Ben-Porath, Y. (1987). Decision making under stress: Scanning of alternatives under physical threat. Acta Psychologica, 64(3), 219-228.

Kelley, H.H., Beckman, L.L. and Fischer, C.S. (1976). Negotiating the division of a reward under incomplete information. Journal of Experimental Social Psychology, 3(4), 361-398.

Komorita, S.S. and Barnes, M. (1969). Effects of pressures to reach agreement in bargaining. Journal of Personality and Social Psychology, 13(3), 245-252.

Lambert, E. and Hogan, N. (2009). Creating a Positive Workplace Experience: The Issue of from Supervisors and Management in Shaping the Job Stress, Job Satisfaction, and Organizational Commitment of Private Correctional Staff. Journal of Applied Security Research, 4(4), 462-482.

Lehman, A.L. (1997). E-Main in the Workplace: Question of Privacy, Property or Principle. CommLaw Conspectus, 5(1), 99-112.

Linquist, E.F. (1989). İstatistiğe giriș. İstanbul, Turkish: MEB Öğretmen Kitapları Dizisi.

MacKinnon, D.P., Warsi, G. and Dwyer, J.H. (1995). A simulation study of mediated effect measures. Multivariate Behavioral Research, 30(1), 41-62.

Mason, D. etal. (2002). On the poverty of apriorism: Technology, surveillance in the workplace and employee responses. Information, Communication and Society, 5(4), 555-572. 
Meyer, R.D. et al. (2014). Measuring jobrelated situational strength and assessing its interactive effects with personality on voluntary work behavior. Journal of Management, 40(4), 1010-1041.

Miller, S. and Weckert, J. (2000). Privacy, the workplace and the Internet.Journal of Business Ethics, 28, 255-265.

Naus, F., Iterson A.V. and Roe, R. (2007). Organizational cynicism: Extending the exit, voice, loyalty, and neglect model of employees' responses to adverse conditions in the work place. Human Relations, 60(5), 683-718.

Newman, A., Thanacoody, R. and Hui, W. (2011). The impact of employee perceptions of training on organizational commitment and turnover intentions: a study of multinationals in the Chinese service sector. The International Journal of Human Resource Management, 22(8), 1765-1787.

Nunnally, J.C. (1994). Psychometric theory 3E. New York, USA: Tata McGraw-Hill Education.

Parker, S.K. (2014). Beyond motivation: Job and work design for development, health, ambidexterity, and more. Annual Review of Psychology, 65, 661-691.

Pieters, R. and Warlop, L. (1999). Visual attention during brand choice: The impact of time pressure and task motivation. International Journal of Research in Marketing, 16(1), 1-16.

Prem, R. et al. (2017). Thriving on challenge stressors? Exploring time pressure and learning demands as antecedents of thriving at work. Journal of Organizational Behavior, $38(1), 108-123$

Rhoades, L. and Eisenberger, R. (2002). Perceived organizational support: a review of the literature. Journal of Applied Psychology, 87(4), 698-714.

Riketta, M. (2008). The causal relation between job attitudes and performance: A meta-analysis of panel studies. Journal of Applied Psychology, 93(2), 472-481.
Semmer, N.K., Zapf, D. and Dunckel, H. (1995). Assessing stress at work: A framework and an instrument. In Svane, O. and Johansen, C. (Eds.), Work and health-Scientific basis of progress in the working environment (pp. 105-113). Luxembourg, Luxembourg: Office for Official Publications of the European Communities.

Sewell, G. and Barker, J.R. (2006). Coercion versus care: Using irony to make sense of organizational surveillance.Academy of Management Review, 31(4), 934-961.

Sipahi, B., Yurtkoru, E.S. ve Çinko, M. (2006). Sosyal Bilimlerde SPSS'le Veri Analizi. İstanbul, Turkish: Beta Yayinevi.

Sobel, M.E. (1982). Asymptotic intervals for indirect effects in structural equations models. In Leinhart, S. (Ed.), Sociological methodology (pp. 290-312). San Francisco, USA: Jossey-Bass.

Stanley, D.J., Meyer, J.P. and Topolnytsky, L. (2005). Employee cynicism and resistance to organizational change. Journal of Business and Psychology, 19(4), 429-459.

Stanton, J. and Stam, K. (2003). Information technology, privacy, and power within organizations: A view from boundary theory and social exchange perspectives. Surveillance and Society, 1(2), 152-190.

Stinglhamber, F. and Vandenberghe, C. (2003). Organizations and supervisors as sources of support and targets of commitment: A longitudinal study. Journal of Organizational Behavior: The InternationalJournal of Industrial, Occupational and Organizational Psychology and Behavior, 24(3), 251-270.

Tabachnick, B.G., Fidell, L.S. and Ullman, J.B. (2007). Using multivariate statistics. Boston, USA: Pearson.

Thoits, P.A. (2011). Perceived social support and the voluntary, mixed, or pressured use of mental health services. Society and Mental Health, 1(1), 4-19. 
Thomas, J.R., Nelson, J.K. and Silverman, S.J. (2015). Research methods in physical activity. Champaign, USA: Human Kinetics.

Thomas, K.W. and Tymon Jr., W.G. (1997). Bridging the motivation gap in total quality. Quality Management Journal, 4(2), 80-96.

Thorndike, R.M. et al. (1991). Measurement and evaluation in psychology and education. Boston, USA: Pearson.

Turgut, T. (2011). Çalışmaya Tutkunluk: İş Yükü, Esnek Çalışma Saatleri, Yönetici Desteği ve İş-Aile Çatışması ile İlişkileri. Atatürk Üniversitesi İktisadi ve İdari Bilimler Dergisi, 25(3-4), 155-179.

Turner, N. et al. (2012). Job Demands-ControlSupport model and employee safety performance.AccidentAnalysis \& Prevention, 45, 811-817.

Tymon Jr., W.G., Stumpf, S.A. and Doh, J.P. (2010). Exploring talent management in India: The neglected role of intrinsic rewards. Journal of World Business, 45(2), 109-121.

Tymon Jr., W.G., Stumpf, S.A. and Smith, R.R. (2011). Manager support predicts turnover of professionals in India. Career Development International, 16(3), 293-312.

Wanous, J.P., Reichers, A.E. and Austin, J.T. (2000). Cynicism about organizational change: Measurement, antecedents, and correlates. Group \& Organization Management, 25(2), 132-153.

Wilkerson, J.M. (2002). Organizational cynicism and its impact on human resources management. In Ferris, G.R., Buckley, M.R. and Fedor, D.B. (Eds.), Human resources management: Perspectives, context, functions, and outcomes (pp. 532-546). New Jersey, USA: Prentice Hall.

Wilkerson, J.M., Evans, W.R. and Davis, W.D. (2008). A test of coworkers' influence on organizational cynicism, badmouthing, and organizational citizenship behavior. Journal of Applied Social Psychology, 38(9), 2273-2292.
Wiltshire, J., Bourdage, J.S. and Lee, K. (2014). Honesty-humility and perceptions of organizational politics in predicting workplace outcomes. Journal of Business and Psychology, 29(2), 235-251.

Yoon, J. and Lim, J.C. (1999). Organizational support in the workplace: The case of Korean hospital employees. Human Relations, 52 (7), 923-945.

Yoon, M.H. and Suh, J. (2003). Organizational citizenship behaviors and service quality as external effectiveness of contact employees. Journal of Business Research, 56(8), 597-611.

Yukl, G.A. etal. (1976). The effects of time pressure and issue settlement order on integrative bargaining. Sociometry, 39(3), 277-281. 